\title{
Managing time for managers
}

\author{
Merle E. Ace \\ University of British Columbia, Vancouver, Canada
}

\begin{abstract}
Although managers are often concerned about their use of time to get more done, there are even more compelling reasons for the effective use of time. Time is important from the perspectives of health, of employee work performance, and of new products. Managers waste time in many ways, including the confusion of activity with results, lack of planning, doing it yourself, misusing an open-door policy, and use of managerial shortcuts. If people want to make better use of their time, they must first admit that most of their time management problems are of their own making. These internal time wasters include failure to set goals and priorities, the tendency to procrastinate, and lack of proper delegation. External time wasters, caused by outside forces, include meetings, the telephone, and interruptions. It is difficult for people to accurately assess their use of time, however, and to pinpoint their time management problems. A time log is sug. gested as an objective means of doing so. Excessive use of a managerial style can lead to time traps. Successful time management is successful self-management, and that means the exercise of self-discipline.
\end{abstract}

S. Afr. J. Bus. Mgmt. 1981, 12: $122-129$

Bestuurders is dikwels oor hul tydbesteding besorg in 'n poging om meer gedaan te kry, maar daar is selfs belangriker redes wat die doeltreffende benutting van tyd noodsaak. Tyd is belangrik gesien vanuit die oogpunte van gesondheid, werkverrigting deur werknemers en nuwe produkte. Bestuurders mors op baie maniere tyd, byvoorbeeld weens verwarring tussen aktiwiteit en resultate, gebrek aan beplanning, alles-self-doen, misbruik van 'n oop-deur beleid en gebruik van bestuurskortpaaie. As bestuurders hulle tyd beter wil benut, moet hulle eers erken dat hulle die meeste van hulle tydbestuursprobleme self veroorsaak. Hierdie 'interne' tydmorsers sluit o.a. 'n gebrek aan bepaling van doelwitte en prioriteite, die neiging om uit te stel en gebrek aan behoorlike delegering in. Eksterne tydmorsers wat deur buitefaktore veroorsaak word, sluit vergaderings, die telefoon en onderbrekings in. Mense vind dit egter moeilik om hulle gebruik van tyd akkuraat te beoordeel en om hul eie tydbestuursprobleme vas te stel. 'n Tydbestedingskaart word voorgestel as 'n objektiewe manier om dit te doen. Oormatige gebruik van 'n bestuurstyl kan lei tot tydslaggate. Suksesvolle tydsbestuur is suksesvolle selfbestuur, en dit beteken die beoefening van selfdissipline.

S.-Afr. Tydskr. Bedryfsl. 1981, 12: $122-129$
'Time is the stuff of which life is made' - Ben Franklin

\section{Introduction}

We often say that today's world is more hurried, less personal and more complex. It seems true. In each new decade undergraduates in university must learn what doctoral students were examining for the first time in the last decade. There is more and more to know and do, and seemingly less time in which to get all these things done. Many managers have become increasingly aware of how precious time is. Our organizations have grown, communications are more difficult, conflict and competition are rampant, and subordinates do not respond as willingly to authority as used to be the case only a few years ago. It seems to take ever more effort to get the simplest tasks done. Managing one's own time effectively has become as critical as managing people. One must be successful at both to perform one's job well.

\section{Time and health}

There are other, even more compelling reasons, for being concerned about time as a manager. Several years ago two medical researchers in California noted that people suffering from heart trouble seemed unusually anxious, stress-ridden and nervous. Were these patients experiencing anxiety because of their hearts, as many would argue? Or, were they experiencing heart trouble because of the anxiety? After months of study, Friedman and Rosenman $^{1}$ came to the conclusion that there is a type of person whose life style is such that the probability of heart attack becomes very high. We know this kind of people as workaholics. Friedman and Rosenman called them 'Type $A^{\prime}$. Type A's eat and walk rapidly. They are impatient, feel guilty when relaxing, and are ever looking for ways of stuffing more work into a day. Because of these characteristics their systems retain more cholesterol which, in turn, makes them more susceptible to heart trouble. Good time management means, in part, organizing one's working life so as to help relieve tension and anxiety.

\section{Employee time management}

Time is important from the standpoint of employee work performance also. It is estimated that about $65 \%$ of the South African gross national product is comprised of
Associate Professor, University of British Columbia, 2075 Westbrook Place, Vancouver BC Canada V6T IW5

( 
wages and salaries. This is the most expensive cost of doing business. We often speak of productivity and worry about motivation. Yet, while managers seem concerned about their own time management, few seem troubled by employee time management. Parkinson's Law states that work expands to fill time available. If an employee is unclear about his or her objectives or how to achieve them, or is unsure of what to do next, the chances are that he or she will not sit idle. They will do anything to appear busy. It is probably safe to say that there is more time lost in busy-work than in absenteeism, tardiness, laziness or lack of motivation. Programmes which detail how to motivate workers may be misplacing the emphasis.

If one thinks back over the products introduced during the last few years it readily becomes apparent that time is important to consumers. Cameras are now equipped with computers so that all that is necessary to take a good picture is to simply point the camera and press a button. The computer makes all those bothersome adjustments which used to take precious minutes with last decade's cameras. Whereas a parent used to fold a cloth nappy, position it while holding safety pins in the mouth, then steady the baby while skillfully managing the pinning, the modern parent uses ready made plastic nappies which come with adhesive tape. In North America plastic bank cards now enable the harried man on the street to do his banking via sidewalk machines, rather than standing in line waiting for a teller. He can now bank 24 hours a day, seven days a week; this frees him from using work time, and, of course, it is faster. In fact, the main advances in products and services make their use time-economic to consumers.

\section{How managers waste time}

(a) Although few would put it into so many words, there are many managers who work as though they believed that those who are the most active get the most done. They confuse activity with results, means with ends, and motion with accomplishment. The effort they put into a task seems to be inversely proportionate to their certainty as to where they are going and how to get there. Activity, originally designed to meet desired ends, ultimately becomes the end itself. Some even take a perverse pride in being able to tell others how busy they have been. These managers have become lost in what George Odiorne has called the 'activity trap'. ${ }^{2}$ They are struggling only for dayto-day survival, having lost sight of their objectives.

(b) One of the principles of management which is learned early is that decisions should be made at the lowest appropriate level, consistent with good judgement and relevant facts. On the other hand it is quite clear to many that people who are paid more make better decisions. This being true, shouldn't all decisions be made at the top? Managers who get sidetracked this way should consider the following:

- lower-level decisions are based on greater familiarity with circumstances,

- higher-level decisions cost more, and

- higher-level decisions take the time of those who might better be devoting it elsewhere, given the above two propositions. (c) It is not unusual to find managers who believe that the most efficient person is the most effective. This confusion of terms can be time costly. A manager may be efficient on the wrong task or at the wrong time, or in the short run, and still be very ineffective in his work. What is the point in trying to do more cheaply what should not be done at all? Efficiency is doing the job right. Effectiveness is doing the right job right.

(d) Delegation is like an old shoe: well chewed. It is well known that delegation involves the need to decide what to delegate, to whom, to communicate the task, to follow-up and to evaluate. All this takes a great deal of time. One saves time by simply doing the task oneself. Not necessarily so. Consider money: money is invested in the short term to earn more money in the long term. In this way, time is like money. Through delegation, time can be invested in the short term to earn more time in the long term. As subordinates grow and develop through being given responsibility, they accept more demanding tasks in the future thus relieving their boss, and giving him or her more time. The interest earned on time invested can be far greater than that earned on money invested.

(e) There is a tendency among too many managers to confuse perspiration with accomplishment, even though end results are seldom proportional to buckets of sweat generated. In academia there is a kind of inverse Pareto principle: three hours of preparation are needed for one hour of doing (teaching). Managers might well take note. Alec Mackenzie shows that one hour of planning can save three hours in execution. In a study he conducted it was found that $20 \%$ in project time could be saved when planning time was doubled. And the results were better! Planning time is an investment. It saves time in the long term. Peter Drucker has said that hard workers do things the hardest way. Work smarter, not harder!

(f) Instructions and checking up take time. If you do it yourself it gets done right the first time. This style of thinking is self perpetuating. Others never learn how. Doing it yourself becomes necessary; there is no other way. This rut is often created when, after a promotion, the manager prefers to continue doing those parts of the old job which were pleasant and which he or she did well. The problem is that when these are added to the new job, time problems result. And the further up the ladder our 'successful' managers go, the more excess baggage they bring with them and the more time management problems they accumulate.

(g) The open-door policy was once introduced to help generate teamwork, better communications and rapport. When carried to an extreme, however, much time can be wasted. It can be an invitation to socialize and chit-chat. Perhaps what is needed now is a closed-door policy. This might be planned unavailability time, that is, specific time(s) during the week when the manager is not available for conversations, telephone calls and meetings. A certain manager practices the open-door policy in an interesting way. 
His door is always open, whether at $7 \mathrm{am}$ or $7 \mathrm{pm}$. No matter when one passes by his office his door stands open. Of course, he is not there. He is somewhere else getting his work done. One need not carry the notion to this extreme. An open-door policy can work - but it must be open at scheduled times for those with work-related problems. And it should be complemented with scheduled time(s) for the door to be closed as well.

(h) It is often believed that identifying problems is the easy part of problem solving. However, there is much time wasted in solving the wrong problems. Some managers, like academics, are known for their highly articulate answers to questions that have not been asked. One needs only to listen to politicians on the campaign trail to realize that they are often guilty of the same misdemeanours. Why solve the wrong problems and answer the wrong questions?

(i) There seems to be an inherent belief among managers that many managerial shortcuts are timesavers. But if the truth were known, these timesavers probably cost more time in the long term. For example, cutting an important conversation short and postponing decision to another meeting, means returning to the original conversation (problem) another day and reviewing the matter. Each return means there is more to review, more time wasted. As a wit once asked, 'If you don't have time to do it right, when will you have time to do it over?'

\section{External and internal time wasters}

When work is going well, things are in order and humming along as they should, the manager will feel satisfied and accept the credit he feels due. After all, if it weren't for him, it wouldn't be this smooth. But when work is not going well, everything seems to be going wrong, the manager will seldom accept the blame. He will probably see at fault his boss, his subordinates, or 'the system'. If there were laws of human nature, this would certainly be one. When any group of managers anywhere in the world is asked to identify their biggest time waster, those obstacles that prevent them from making better use of their time, they invariably name problems associated with their boss, their subordinates or the company. Prominent are 'telephone', 'interruptions', 'meetings', 'post', and 'employees with problems'. These problems might be labelled external time wasters because they have in common the quality that they are all outside the manager's sphere of influence; they are characteristics of the company and people with whom he works. He is not to blame or at fault.

Interestingly enough, when the same managers are asked to analyse either a written case or a film and identify the biggest time wasters of managers therein, invariably they name problems associated with the individual's style of management, his behaviour, and personality. As outside observers, they are quick to see that time management problems such as 'lack of goals', 'failure to listen', 'attempting too much', 'procrastination' and 'doing it oneself' are all too frequent. These might be labelled internal time wasters because they have in common the quality that they are all within the manager's sphere of influence and they are characteristic of him as a person.
This is clearly the area in which the greatest improvements in time management effectiveness can be made, but it is not possible to do so until it is recognized and accepted that indeed, these internal problems are the real culprits.

\section{Coping with external time wasters}

These problems are, by definition, to a large extent outside the influence of the individual manager. However, there are ways of minimizing their disruptive influence, and it is these which will be discussed for three of the most common problems.

\section{Meetings}

Although managers feel that they have far too many meetings, it is estimated that academics have about $20 \%$ more. This may be a kind of tribute to the democratic management which academics enjoy - or a price they pay! But number of meetings aside, of equal concern is the productiveness of the meetings. A survey conducted by ALCOA in Western Australia recently pinpointed three causes of wasted time in meetings. First, they were too large. Too many were invited to attend. For example, two engineers would be asked when only one was necessary. The optimum size for a working meeting is six to eight individuals. Second, it was felt that meetings were sloppily run. Attendees were often not provided with a clear agenda, and discussions frequently wandered from the topic. Third, and most important, people were careless with follow-up to meetings. Minutes were not produced, actions and responsibilities were not recorded and as a result, a subsequent meeting often had to start at the beginning again. To make better use of meeting time, use can be made of the following five steps:

(i) Think through objectives in advance, be clear about what the meeting is to achieve.

(ii) Keep members informed about what is to be discussed and why.

(iii) Arrange the agenda so as to allot more time to important items, less time to the merely urgent.

(iv) Structure the discussion and stay to the point.

(v) Summarize and record decisions taken and action plans including responsibilities.

\section{Telephone}

Because I had often received late and garbled messages, I installed a telephone recording device on my desk three years ago. It has been a surprising boon to my time management. When a person calls, a recorded message answers saying I am out of the office just now, but if they would leave their name, number and concern, I will call back as soon as possible. Only two out of five callers do so. The other three callers obviously have matters of little importance. If I had answered the telephone personally I would not have been using my time in the best way. There are other advantages to this machine. When I call back in response to a recorded message I can prepare to discuss the topic beforehand rather than being caught flatfooted and forced to deal with it off the top of my head. Recorded messages are accurate - 1 seldom get them garbled. Recorded messages are timely - I get them immediately. And if I so wish, I can actually listen to the caller recor- 
ding his or her message. If the matter is one I want to discuss quickly I can simply pick up the telephone and cut in.

It makes good time sense to group your outgoing telephone calls to specific times. If someone is unavailable to you at that time, say you'll call back. You'll have better control of your time that way because you'll have your notes ready and your mind geared for the call. Another good idea is to keep a telephone interrupters log. This might be simply a page near the telephone. Note who calls, when, and why. Spot the unnecessary interrupters, then meet with them and mutually agree to save comments and questions for one meeting a day or week. In these ways you can minimize and to some extent control telephone interruptions.

\section{Interruptions}

A manager without any face-to-face interruptions during his working day is probably not really holding a management job. Providing guidance and decisions for sudden problems is one critical reason the job exists. But handling these necessary interruptions skilfully is good time management. Tell callers about your priority. Keep a pencil or pen poised in your hand. Stand to meet callers and don't encourage them to sit by doing so yourself. If they sit anyway, do not follow suit. Perch on the corner of your desk or chair. Offer to meet callers in their office. It gives you the option to leave when you feel the problem is solved. Visitors in your office have invaded your territory and they retain the option to terminate. Encourage them to be brief. Be up front in your concern for your own time use. Glance at your watch or clock openly. Stand up and move towards the door if necessary. Ask that their problem be put in a memo (problems have a way of evaporating when put into black and white). Say, 'I won't take any more of your time now!' The principle is to be ruthless with time, but gracious with people.

\section{Coping with internal time wasters}

This type of time problem is the most important because we have the most direct control of it. We can therefore effect more dramatic changes in our time management. Consider the following three most often mentioned time problems.

\section{Goals and prioritizing}

Establishing goals and their relative importance may be the single most time effective area in which improvements can be made. Alan Lakein ${ }^{3}$ has recommended a four step procedure for good time management:

(i) Prepare a To-do List. Identify A, B and C priorities.

(ii) Start with the A's, not the C's.

(iii) Handle each piece of paper only once.

(iv) Finish what you start. Don't procrastinate!

This is excellent advice, but deceptively simple. Let me explain.

A To-do List might be a 3 by 5 -inch card you carry in your pocket on which you note all those things you want to do the next day. The best time to complete the To-do List is last thing before you leave your office at the end of the work day. This is an easy means of establishing daily goals for yourself in an informal way. You will feel a sense of accomplishment when you see all the items you have completed and crossed off at the end of the day.

Once you have completed your list, decide their relative importance, that is, priorities. Managers usually attend to things in terms of their urgency. Urgent matters have time constraints attached. Little, urgent things often get done first so that the 'field is clean' and we can get on to the big, important things. When we prioritize in this way we usually find that we never do get to the big important things which take more time. It is very helpful to differentiate in your mind the dimension of importance from the dimension of urgency, and to combine them in establishing priorities:

- Priority 1 - important and urgent (a report due l0am tomorrow)

- Priority 2 - important, but not urgent (physical check-up with doctor)

- Priority 3 - urgent, but not important (you are asked to give a speech)

- Priority 4 - not important and not urgent (busy-work, diversionary, gives one the feeling of activity)

- Priority 5 - wasted time (you feel bad after having done it).

We have little trouble in recognizing items which are Priority 1 or Priority 5. We confuse our priorities by moving items in Priority 3 and 4 ahead of Priority 2. Priority 2 consists of all those things which we have promised ourselves we must do, but which we never seem to get around to. Why? There are no time constraints attached. The rule here is to attend to those items first in terms of their importance, and second in terms of their urgency.

Setting goals for oneself to make better use of time should not be confined to daily routine, however. Lakein also advises managers to ask themselves exactly what their life-time goals are (things to be accomplished by the time the age of 80 is reached), what their professional goals are (things to be accomplished by the age of retirement), and what their short-term goals are (things to be accomplished in the next six months). These goals must be specific (for example, a certain salary or a savings account figure, rather than a higher salary or to be rich). They must also be realistic, that is, things you really want and are willing to work for. Establish the most important items from each of the three categories. Write them down and post the list where you can see it every day. Ask yourself, 'Is what I am doing now moving me closer to one of my goals?" If not. are you not wasting your time? Think about it.

\section{Procrastination}

This represents a human frailty which we all fall prey to on occasion. If it is found that an item on your To-do List must be moved forward to the next day more than once, procrastination may be suspected. Here are three methods of coping with the problem.

Divide and Conquer. If the whole task is, or seems to be, too much, slice it into small manageable pieces, each 
quick and simple. Take one at a time. Write each down. Suppose you have an unpleasant phone call to make, and you realize you are procrastinating. You might cut it up like this:

(i) look up telephone number and write it down

(ii) set a time to make the call

(iii) review the file

(iv) decide what to say

(v) finally, place the call.

Balance Sheet. Ben Franklin developed this approach for solving the problem. Divide a sheet of paper into two columns. On the left list all your reasons for procrastinating. On the right list all the benefits of getting the job done. The effect is usually so lopsided and striking that it is enough to get you going.

Worst is First. If procrastination is really habitual with you then this may be the best method to use. It is based on the notion that an ineffective person will think to himself, 'This must be done, but it is unpleasant, therefore I will put it off as long as I can'. An effective person will think, 'This task is unpleasant, but it must be done, therefore I will do it now so I can forget about it'. First, decide to make the change immediately. Taking this first step is important. Second, don't try too much, just force yourself to do one thing you have been putting off. Choose the most unpleasant thing on your To-do List, and do it first thing tomorrow morning. It will give you a feeling of exhilaration. The day is only a few minutes old and the worst part is over already. Because it is self-reinforcing, it can develop a new habit. But do not make any exceptions during the first two weeks. Like winding a ball up a string, one slip undoes a lot of work.

\section{Delegation}

During my years as a teaching assistant in graduate school I was amused to discover that in every class I asked, over $90 \%$ of the students claimed they were in the top quarter in terms of driving ability. Obviously it is not because students are more able drivers than are others, it is simply because this is one skill practically everyone believes they excel in. Delegation is like driving ability. Most managers believe they do it very well. There is little to discuss. They have heard it all before. Before you read any further, take a minute to answer the following ten questions 'yes' or 'no' as honestly as you can.

\section{Rate yourself as a delegator}

- Do you take work home regularly?

- Do you work longer hours than your subordinates?

- Do you spend time doing for others what they could be doing for themselves?

- When you return from an absence from the office, do you find the in-basket too full?

- Are you still handling activities and problems you had before your last promotion?

- Are you often interrupted with queries or requests on going projects and assignments?

- Do you spend time on routine details that others could handle?
- Do you like to keep a finger in every pie?

- Do you rush to meet deadlines?

- Are you unable to keep on top of priorities?

There are surprisingly few managers who answer less than seven of these questions 'yes'. Yet, if you have found than seven or more of your answers were 'yes' you should think again about your ability to delegate. You are doing too much yourself!

There are many reasons why delegation is not used more often. Some of them are perfectly legitimate. Some subordinates, for example, are not intelligent or responsible enough to handle delegation. But managers are often quick to make this sort of assumption and use it as an excuse. It is more often the case that the barriers to delegation lie within the manager himself. Consider these personal reasons for not delegating:

- preference for operating, doing it oneself

- 'I can do it better myself'

- insecurity or fear of being disliked

- refusal to allow mistakes

- lack of confidence in subordinates

- uncertainty over tasks

- inability to explain

- disinclination to develop subordinates.

Edwin Bliss ${ }^{4}$ offers this parable which should help remind us that a bit of courage is necessary:

\section{Delegation: A Parable}

Once upon a time there was a Little Red Hen who owned a wheat field. 'Who will help me harvest the wheat?' she asked.

'Not I,' said the pig. 'I don't know how.'

'Not I,' said the cow. 'I'm too clumsy.'

'Not I,' said the dog. 'I'm busy with some other things.'

So the Little Red Hen did it herself. 'Who will help me grind the wheat into flour?' she asked.

'Not I,' said the pig. 'That is another vocation in which I'm untrained.'

'Not I,' said the cow. 'You could do it much more efficiently.'

'Not I,' said the dog. 'I'd love to, but I'm involved in some matters of greater urgency. Some other time, perhaps.'

So she did it herself. 'Who will help me make some bread?' asked the Little Red Hen.

'Not I,' said the pig. 'Nobody ever taught me how.'

'Not I,' said the cow. 'You're more experienced and could do it in half the time.'

'Not I,' said the dog. 'I've made some other plans for the afternoon. But I'll help you next time.'

So she did it herself.

That evening, when guests arrived for her big dinner party, the Little Red Hen had nothing to serve them except bread. She had been so busy doing work that could have been done by others that she had forgotten to plan a main course, prepare a dessert, or even get out the silverware. The evening was a disaster, and she lived unhappily 
ever after.

Moral: A good leader will find a way to involve others to the extent of their ability. To do the job yourself is the chicken way out.

\section{The treachery of memory}

Many of us have had the experience of arriving home at the end of a working day and being asked by our spouse what happened at the office. It was a busy, exhausting day. But upon reflection trying to describe it in all its awful detail, we find to our surprise that the detail just isn't there. After several minutes of thought we confess we can't remember. It was just hectic, that is all. Our memories are not reliable when trying to remember detail, unless it was very pleasant. In an experiment conducted with school children just back from Christmas holidays, the class was asked to write down all the pleasant happenings they could recall in one column on a piece of paper, and all the unpleasant happenings in another column. Their names were signed and the lists were given to the teacher. A month later the teacher asked the class to go through the same exercise. It was discovered that $80 \%$ of the pleasant happenings were recalled on the second occasion, but less than $30 \%$ of the unpleasant happenings were recalled. Much of what happens in a typical working day is not so pleasant that we can recall it with any degree of accuracy.

In Toronto, the president of a large multinational organization was asked to estimate how his time was used in seven categories. The total was to equal $100 \%$. After having done so he agreed to allow an observer to record his activities for a two-week period. The results in Table 1 show how far off the mark his own estimates were. There is a tendency for managers to overestimate the time spent in activities they find unpleasant and to underestimate the time spent in activities they find pleasant. It might be inferred from Table 1 that this president found planning and controlling somewhat unpleasant, although important and necessary, while civic activities and plant visits were felt to be more pleasant. Whatever the explanation, it is clear that our memory does play tricks on us. The only objective way of knowing what happens to your time is to keep track of it - a time log.

Keeping a time log is often felt to be an imposition, another dollop of detail in an already overdetailed job. This need not be the case. A time log may be as simple as a lined pad of paper on one corner of the desk, on which

\section{Table 1 Time profile of a president}

\begin{tabular}{lcc}
\hline Activity & $\begin{array}{c}\text { Estimate } \\
\%\end{array}$ & $\begin{array}{c}\text { Actual } \\
\%\end{array}$ \\
\hline 1. Planning & 50 & 30 \\
2. Reports and control & 20 & 10 \\
3. Staff meetings & 15 & 21 \\
4. Secretary dictation & 5 & 3 \\
5. Telephone & 5 & 8 \\
6. Civic activities & 5 & 20 \\
7. Plant visits & 0 & 8 \\
\hline & 100 & 100 \\
\hline
\end{tabular}

a running record is kept every half hour (at most, every hour) of all the telephone calls, interruptions, letters and memos dealt with, and meetings. Each activity must be recorded together with the people involved, the topics, and length of time. At the end of one week the data is examined. The result of such a self-analysis will usually come as a shock, but knowing exactly where your time was used puts you in a much better position to make needed improvements. Obtaining a clear picture of where your time is being spent this way should not be a one-shot effort. To maintain effectiveness and to be sure changes made lead to further improvements, one should keep a time log periodically, that is, once every six months, for example.

\section{Time orlentations}

Time may be considered objectively, that is, as the ticking off of seconds on a clock. Physicists have defined time in terms of the constant rate of decay of strontium 90 . Dictionaries define time as a non-spatial continuum along which events are apparently irreversibly ordered. People who look at time in this way are being objective. They see time as linear, flowing from the past, through the present to the future.

Time may also be considered subjectively, that is, emotionally. People feel that time drags when they are bored, or passes them by when they miss out on something, or marches on when they look back. Ben Franklin's quote at the beginning of this article represents this point of view. Most people live time subjectively. They fall into one of three categories: A roving reporter for a daily newspaper in Vancouver once asked high school students 'What is your favourite daydream?' One student answered, 'I like to think about the good times I had last weekend'. This person is oriented to the past. A second student answered, 'Well, my daydreams usually involve a lot of blonde ladies ...' We could say that this fellow is oriented to the present. The third student answered, 'I like to think about the good times I'm going to have on the weekend'. Clearly, this student is oriented to the future. These three students represent the three subjective time categories to which most people belong.

\section{Management styles}

Managers also have characteristic behavioural styles they use when dealing with others. Most managers are aware of their primary style of management. However, they often are not aware that their primary style of management may lead to time management problems. There is the story of the small boy who was given a hammer by his father, and in the course of events, discovered that everything he encountered needed pounding. It was the only tool the boy had. So it is with managers. If their primary style is the only tool they have, every problem they encounter must require the use of that specific style. All problems get pounded! When this happens these managers can be said to be using their style 'in excess'. The notion of excess is depicted in Figure 1.

One way of determining a manager's effectiveness is to ask if his or her style being used is appropriate to the task at hand. If it is not, the manager's effectiveness is diminished. Clearly, if a manager only has one style 


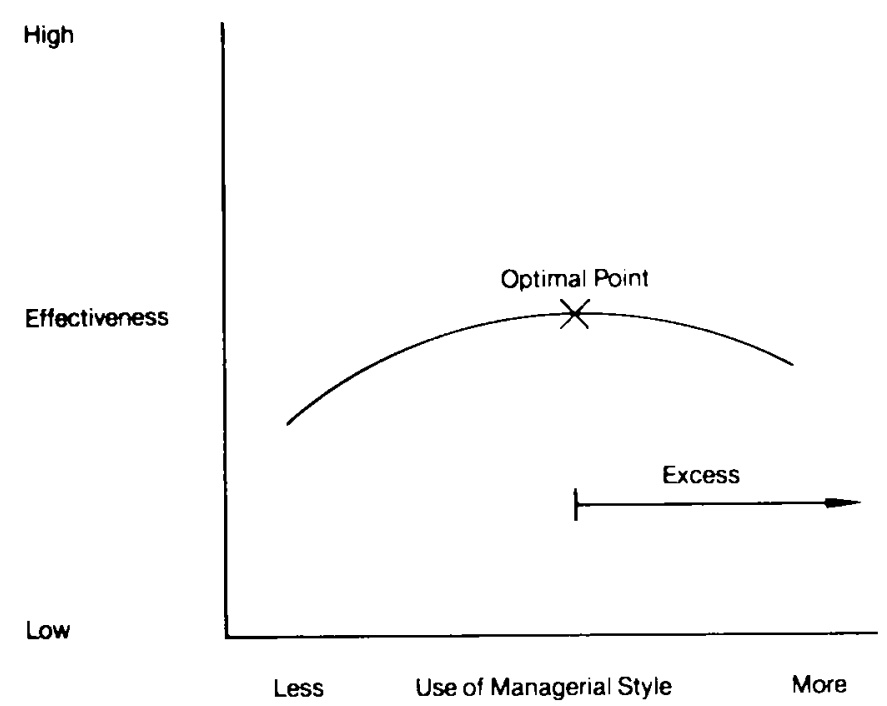

Figure 1 The dysfunction of trying too hard

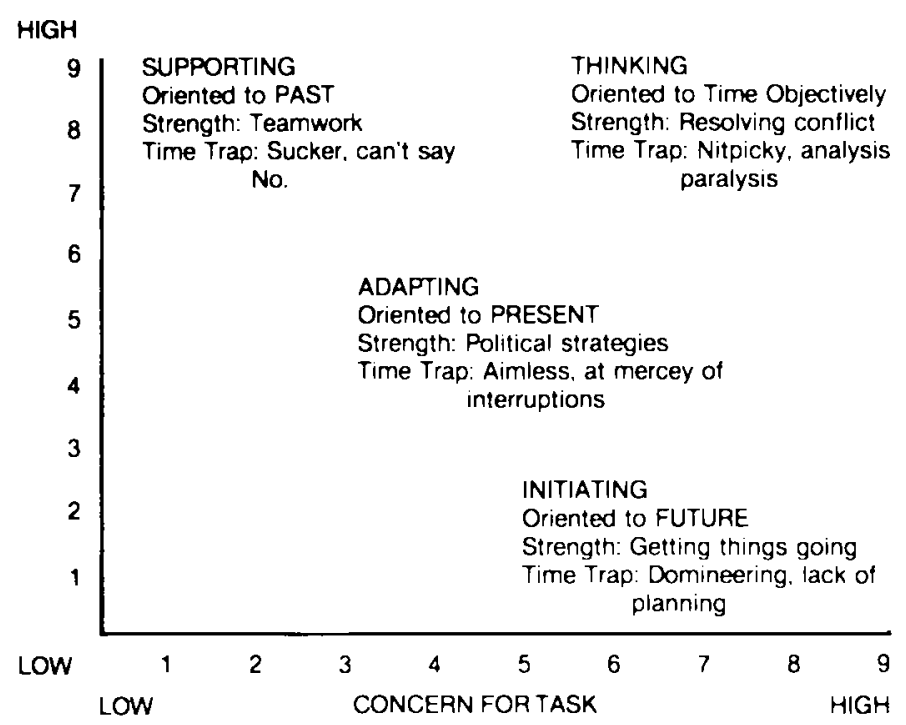

Figure 2 The managerial time grid

available, there will be many occasions when he or she is not dealing with matters in the most effective way. The one style will be effective, but only up to a point. After reaching this point, when a style is used in excess, his effectiveness decreases or disappears.

\section{Time traps}

When managers use a style in excess they also create time problems for themselves. They can be said to fall into time traps. In Figure 2 the four most common styles of management are illustrated. In each case the most descriptive adjective of the style is given, the time orientation, the greatest strength of the style, and the most probable time trap ${ }^{5}$ when using the style in excess.

The manager high on concern for people and low on concern for task is supporting. An orientation to the past is used to develop and strengthen personal relationships by way of recalling shared experiences. This manager is helpful, cooperative, thoughtful in dealing with others and has the strength of generating good teamwork: However, when this style is used excessively, the manager is perceived as a sucker, someone who will accept anything rather than face a hassle if he should say 'no'. The result is a pile-up of work with impossible deadlines.

The manager who has moderate concern for both people and task is adapting. An orientation to the present means this manager is only intent on getting through another day. Just coping with the here and now is all he considers. To do so, he has developed a keen sense of how to do things expediently. To this end he is creative, tactful and evaluative. If a plan requires that loopholes be pinpointed, all the weaknesses be listed, he is the person to do it. His strength is his store of political strategies. But, when this flexible style is overused, the manager is perceived as being aimless. He is at the mercy of anyone who can put a bit of pressure on him, and every interruption must be attended to on the spot.

The manager who is low on concern for people and high on concern for task is initiating, with the great strength of getting things going. Persuasive, controlling and confident, his orientation is to the future. He is a doer, rather than a thinker. And, when this style is carried to excess, he is usually perceived as domineering. He suffers from his aversion to thinking things through, planning ahead. For this reason priorities are often confused and although he is busy constantly, the really important items are tackled last.

The last type is the manager who is high on concern for people and high on concern for task. He is thinking, and can be described as being practical, logical and thorough. His strength is in handling differences of opinion, resolving conflict. He is the rare sort of person who not only is oriented to time in an objective way, but also approaches work problems objectively, or non-evaluatively. While this can be a great strength, it can also lead to a time trap when used in excess. The manager will be perceived as nitpicky, a perfectionist, who is always seeking that additional bit of information. This has been dubbed 'analysis paralysis'.

As we all know, there is no one best style of management. It all depends on the situation we are facing. Our primary style can be a real strength. It can also lead to time management problems. Whatever your style, you should beware of the time trap it may cause you. No style is without its difficulties when overused.

\section{Conclusion}

There is a single, critical element which all of these suggestions have in common. If you are sincere in your desire to improve your use of time, and if you really want to adopt any of these suggestions, you must exercise a great deal of self-discipline. Managing time effectively means managing oneself effectively. Only you know how!

\section{References}

1. FRIEDMAN, MEYER \& ROSENMAN, R.H. Type A Behaviour and Your Heart. New York: Fawcett, 1978.

2. ODIORNE, G.S. Management and the Activity Trap. New York: Harper \& Row, 1974.

3. LAKEIN, A. How to Get Control of Your Time and Your Life. New York: McKay, 1973.

4. BLISS, E.C. Getting Things Done. London: Bantam Books, 1976.

5. MACKENZIE, A. The Time Trap. New York: American Management Association, 1972. 


\section{Recommended bibliography}

CONRAN, S. Super Woman. New York: Croun, 1978.

McCAY, J.T. Management of Time. Englewood Cliffs. New Jersey: Prentice-Hall, 1959
SMITH, M.J. When I Say No, I Feel Guilty. New York: Dial, 1975

URIS, A. The Executive Deskbook. New York: Van Nostrand Reinhold, 1979 